Dar es Salaam, Tanzania

six.buguzi@gmail.com

Cite this as: BMJ 2021;373:n1052

http://dx.doi.org/10.1136/bmj.n1052

Published: 27 April 2021

\section{Covid-19: Counting the cost of denial in Tanzania}

\section{For much of the pandemic, Tanzania's government has denied the seriousness of the pandemic. Its doctors are facing the consequences, writes Syriacus Buguzi}

\section{Syriacus Buguzi science journalist}

Tanzania is facing a second wave of the covid-19 pandemic, yet Godbless Charles, a researcher with the Liverpool School of Tropical Medicine who is based in Dar es Salaam, still doesn't have official epidemiological data to tell whether transmission is ongoing, has stopped, or is low or high.

What worries him most is the narrow basis on which he can explain the long term impact of disease on the Tanzanian population. Recommended treatment may differ from that in Europe or other high income countries, not least because stocks of ventilators and oxygen, among other things, are lower in comparison. Charles wants to base recommended treatments on the way covid-19 behaves in local patients. "We would have established this through following up patients, but we don't have a locally established database," he says.

This is because in June 2020, then president John Magufuli stopped the release of covid-19 data, such as case numbers and deaths, saying it was "fuelling public panic." He declared Tanzania "covid-19-free," claiming a three day prayer had saved the country. By then, 509 cases and 21 deaths had been documented.

"Because of sensitivities around the pandemic at the time, there has been a lot of self-censorship on the part of researchers," says a scientist based in the capital Dodoma, who asked to remain anonymous. "Anything to do with covid has had to be scrutinised to see if it goes against the official narrative."

The country's then chief medical officer Abel Makubi has downplayed such concerns. "All we insist is that the research should be in line with national priorities," he said at a 11 March 2021 visit to Muhimbili University of Health and Allied Sciences in Dar es Salaam.

For much of the past 12 months, the government has downplayed the seriousness of the pandemic. As recently as February, permanent secretary of the Ministry of Health Mabula Mchembe told the media that "not every death is necessarily from covid-19," and blamed social media rumours. ${ }^{1}$ But the truth is not so easily dismissed.

\section{Doctors gagged}

After an initial burst of cases, the summer of 2020 saw Tanzania's first wave of covid-19 subside, for reasons not fully understood. But since the beginning of 2021, reports of people dying after a brief illness associated with breathing difficulties have spread on social media, hinting at a second wave underway.

According to Tanzanian public health laws, however, only the government can declare a disease outbreak.
New regulations were introduced in July 2020 further to control information posted about the pandemic online. A person who breaks the regulations is "liable to a fine of not less than five million shillings (£1550; $€ 1796$; \$2157) or to imprisonment for a term of not less than twelve months or both." 2

As a consequence, doctors felt unable officially to diagnose covid-19 for fear of government reprimand. The Medical Association of Tanzania gave a carefully worded public statement with covid-19 listed as one of several possible causes of the rise in deaths. ${ }^{3}$ "We were struggling to stand our ground as doctors to warn the public about covid," says Shadrack Mwaibambe, president of the association. The association resorted to using vague terms-people were dying from "breathing problems," or their deaths were attributed to pneumonia, asthma, or heart disease. "All that doctors wanted to hear was that they were free to diagnose covid-19, nothing else,” says Mwaibambe.

On 27 February 2021 Elisha Osati, a pulmonologist at Muhimbili National Hospital, appeared on television to address the pandemic publicly. It was already two months into the government's public denial of a second wave of the virus. "Doctors will be blamed one day for not doing our part," he told the host of TV show Mtazamo. "We are used to treating people with heart disease and respiratory infections. What we are seeing right now is different."

"As a clinician, I saw many patients who died during died but also health workers and relatives." According to Osati, a covid-19 response team was initially appointed by the Ministry of Health in early 2020 when it followed World Health Organization guidance on the SARS-CoV-2 outbreaks. Over April and May, the response team drafted treatment guidelines for the disease but these were never used-Magufuli's declaration meant the disease couldn't officially exist in Tanzania. Osati, who was part of the reviewing team, says the guidance remains unapproved and was never officially released.

"Throughout this time of denial, every hospital has been relying on its own protocols to handle patients with covid. This has been a serious drawback for medical practice in general," he says.

Zakayo Mmbaga, a general physician based in Dar es Salaam, says, "Seeing patients lose life in front of me just because we have no access to oxygen therapy and adequate intensive care units left me demoralised, yet you would see someone influential on television saying the disease doesn't exist, claiming that people were dying from mere anxiety." that time," Osati told The BMJ. "Not just patients who 
"Most public hospitals resumed normal practice as though there was no covid," he told The BMJ. "There was no active government task force dealing with the pandemic. People believed the virus doesn't exist in Tanzania. There was no planned supply of protective gear to health workers."

\section{Herbal remedies}

It wasn't just doctors. The Tanganyika Law Society reported in a statement that 25 of its lawyers had died in a month, as it urged the government to begin surveillance of the pandemic. Even the Catholic Church pressed the government to follow the science after more than 25 priests and 60 nuns died in two months after reporting breathing difficulties. Charles Kitima, secretary of the Tanzania Episcopal Conference who led an advocacy campaign against denial of the pandemic, told The BMJ, "Even if the government doesn't confirm the outbreak, we have a duty to protect lives. That's why we started advocating social distancing, wearing masks, and hand hygiene."

Yet when Minister of Health Dorothy Gwajima finally tackled the matter on 1 February 2021, she advocated unproved remedies. In a widely circulated video, she and her husband are seen covering themselves with a blanket to inhale steam from a saucepan of herbs.

On 20 February, WHO director general Tedros Ghebreyesus urged Tanzania to share data, take robust action against the pandemic, and accept vaccination. ${ }^{4}$ Two days later, President Magufuli finally began to change his tune, unable to ignore the increasing calls for action and a string of deaths of high profile officials, including the first vice president of Zanzibar, the only government leader to have made public his positive covid-19 test result.

Magufuli, who for two months maintained that God stood by the nation and that there was no covid-19 in Tanzania, died on 17 March, reportedly of heart disease.

Following his death, vice president Samia Suluhu Hassan was sworn into power and has reportedly pushed for more transparency in government reporting. On 11 March 2021, Makubi said that a team of scientists had been tasked to assess which covid-19 vaccine would be suitable for Tanzania. The ministry declined to comment when contacted for further details.

Mmbaga says the Magufuli government's stance made people believe that covid-19 is a trivial condition, while also leading them to delay going to hospital, as they believed it could be treated easily with local herbs. This has undermined the public's trust in conventional medicine. It remains to be seen if that can be regained.

\section{Commissioned, not peer reviewed.}

Competing interests: I have read and understood BMJ policy on declaration of interests and have no relevant interests to declare.

1 Wizara ya Afya Tanzania. Twitter. 3 February 2021. [Swahili] https://twitter.com/wizara_afyatz/status/1356994906296897540.

2 Tanzania Communications Regulatory Authority. Electronic and postal communications act. 2020 www.tcra.go.tz/document/The\%20Electronic\%20and\%20Postal\%20Communications\%20(Online\%20Content)\%20Regulations,\%202020.

3 Zitto MwamiRuyagwa Kabwe. Twitter 15 February 2021. [Swahili] https://twitter.com/i/web/status/1361370974051000322.

4 WHO. WHO director general's statement on Tanzania and covid-19. 20 February 2021. www.who.int/news/item/20-02-2021-who-director-general-s-statement-on-tanzania-and-covid19\#. 